\title{
Synthetic mesh placement in the presence of abdominal infection: An experimental study of feasibility
}

\author{
(1) Ahmet Burak Çiftci, M.D.,, ${ }^{1}$ Rıza Haldun Gündoğdu, M.D., ${ }^{2}$ (Bahadır Osman Bozkırlı, M.D., ${ }^{3}$ \\ (D) Mustafa Ömer Yazıcıoğlu, M.D., ${ }^{2}$ ๑ Berrak Gümüşkaya Öcal, M.D., ${ }^{4}$ @ Birsen Özdem, M.D. ${ }^{5}$
}

\author{
${ }^{1}$ Department of General Surgery, Bingöl State Hospital, Bingöl-Turkey \\ ${ }^{2}$ Department of General Surgery, Ankara Atatürk Training and Research Hospital, Ankara-Turkey \\ ${ }^{3}$ Department of General Surgery, Ankara Training and Research Hospital, Ankara-Turkey \\ ${ }^{4}$ Department of Pathology, Ankara Atatürk Training and Research Hospital, Ankara-Turkey \\ ${ }^{5}$ Department of Microbiology, Ankara Atatürk Training and Research Hospital, Ankara-Turkey
}

\begin{abstract}
BACKGROUND: There are varying opinions on the feasibility of the placement of synthetic materials in contaminated surgical fields. The aim of this study was to investigate the outcomes of the use of a commercially available composite mesh in the presence of abdominal infection.

METHODS: Twenty-four hours after the induction of experimental peritonitis, 20 rats were randomized into 2 groups of 10 subjects. After abdominal cleansing with a second laparotomy, the abdomen was closed with running sutures in the control group and the composite mesh was applied in the experimental group before closure. The rats were followed up for findings of sepsis, mortality, and wound infection. On the $28^{\text {th }}$ day, the rats were sacrificed and evaluated for abdominal infection, abdominal adhesions, and bacterial growth in the mesh and tissue cultures.
\end{abstract}

RESULTS: The mortality rate was $0 \%$ and $30 \%$ in the control and mesh groups, respectively $(p=0.21)$, and the wound infection rate was $20 \%$ and $57.1 \%(p=0.162)$. In the mesh group, the adhesions were significantly more intense $(p=0.018)$ and significantly more microorganisms proliferated in the tissue cultures $(p=0.003)$.

CONCLUSION: The significant increase in the intensity of adhesions and bacterial proliferation, as well as the higher rate of mortality and wound infection in the mesh group indicated that this composite mesh cannot be used safely in the repair of abdominal defects in the presence of abdominal infection.

Keywords: Adhesion; composite mesh; infected field; mesh infection; peritonitis.

\section{INTRODUCTION}

The widespread use of prosthetic materials in the repair of ventral-incisional hernias has dramatically reduced the hernia recurrence rate, and the use of prosthetic mesh has practically become the standard protocol for treatment in this field. [I] In some situations, however, mesh infections and the formation of adhesions make the use of these prosthetic materials controversial. ${ }^{[2]}$ Especially in the presence of contamination, prosthetic mesh application is avoided by most general surgeons for fear of complications such as mesh infection, adhesion formation, enterocutaneous fistula, and intestinal obstruction. This drawback makes the management of large, contaminated facia defects caused by emergency situations a challenge.

In some published studies, the use of synthetic mesh in the presence of abdominal infection or contamination is acknowledged to be contraindicated and biologic mesh placement is recommended in these situations. ${ }^{[3-5]}$ However, probably due

Cite this article as: Çiftçi AB, Gündoğdu RH, Bozkırlı BO, Yazıcıŏlu MÖ, Gümüşkaya Öcal B, Özdem B. Synthetic mesh placement in the presence of abdominal infection: An experimental study of feasibility. Ulus Travma Acil Cerrahi Derg 2018;24:501-506.

Address for correspondence: Bahadır Osman Bozkırlı, M.D.

Ankara Eğitim ve Araştırma Hastanesi, Genel Cerrahi Kliniği, 06340 Ankara, Turkey

Tel: +90 312 - 5953437 E-mail: bbozkirli@gmail.com 
to collagenase activity, biologic mesh loses its surface area and biomechanical characteristics in time and it may also have poor incorporation and integration, which may result in recurrence. ${ }^{[3,6]}$ Furthermore, the high cost of these biologic materials is another disadvantage of these meshes when compared with synthetic materials. ${ }^{[3,7]}$ Recent studies have reported some synthetic meshes to be as resistant to infection as the biologic meshes. ${ }^{[8-10]}$

In emergency situations, which may result in very large, contaminated, abdominal defects, there are different opinions on the feasibility of the use of prosthetic materials for the repair of these defects. This controversy in the literature makes the placement of synthetic materials in contaminated fields a subject that remains worthy of investigation. The aim of this study was to investigate the feasibility of the use of a commercially available synthetic composite mesh (Ventralight ST; Davol Inc, subsidiary of C. R. Bard, Inc., Warwick, RI, USA), composed of an absorbable anti-adhesive barrier and a light polypropylene component, for intraperitoneal placement in the presence of experimental peritonitis.

\section{MATERIALS AND METHODS}

After receiving the approval of the ethics committee for laboratory animals of Ankara Training and Research Hospital, this study was performed in the experimental research laboratory of Ankara Training and Research Hospital. Twenty male Wistar Albino rats, weighing between 250 and $300 \mathrm{~g}$ were used for this study. The rats were kept in cages at $23^{\circ} \mathrm{C}$, with 12-hour light and dark cycles and free access to standard rat food and tap water.

After the induction of anesthesia with an injection of $80 \mathrm{mg} /$ kg of ketamine (Ketalar; Pfizer, Inc., NY, NY, USA) and 5 mg/ kg xylazine (Rompun; Bayer AG, Leverkusen, Germany), the abdominal hair of the rats was shaved. Under sterile conditions, the abdominal cavity was entered via a $3-\mathrm{cm}$, vertical, midline incision. Peritonitis was induced using the cecal ligation and puncture model. ${ }^{[1]}$ The cecum was ligated distally to the ileocecal valve with a $3 / 0$ polyglactin suture (Vycril; Ethicon, Inc., Somerville, NJ, USA) and the ligated cecum was perforated distally to the ligation with the tip of an I8-G needle. After the intestinal content was observed from the perforation site, the cecum was replaced in the abdomen and the abdomen was closed with a 4/0 polypropylene running suture (Prolene; Ethicon, Inc., Somerville, NJ, USA). The rats were then returned to their cages with free access to rat chow and water and were followed for 24 hours. At the end of the $24^{\text {th }}$ hour, the subjects were randomized to 2 groups with 10 rats in each group. After the induction of general anesthesia using the aforementioned method and the application of a single intramuscular $6 \mathrm{mg} / \mathrm{kg}$ dose of gentamicin (Gensif; Avicenna Farma, Istanbul, Turkey), the rats were re-operated on under sterile conditions. To confirm peritonitis, swab cultures were taken from every quadrant of the abdomen. Necrotic cecal tissue was found and resected, and the abdomen was rinsed with $20 \mathrm{cc}$ of warm saline. The abdomen was then closed with a running $4 / 0$ polypropylene suture in the first group. In the mesh group, a $4 \times 2-\mathrm{cm}$, rectangular Ventralight ST mesh was placed intraperitoneally and fixed to the abdominal wall with 3 transmuscular 4/0 polypropylene sutures on each side. The abdominal wall was then closed with a $4 / 0$ polypropylene suture. The skin was closed with a $4 / 0$ Vycril suture in both groups.

Throughout the rest of the study (28 days), the rats were observed for findings of sepsis (apathy, piloerection, diarrhea, ocular bleeding, etc.), death, and findings of wound infection. At the end of the $28^{\text {th }}$ day, the rats were sacrificed with a high-dose ketamine injection. After shearing the hair and performing skin disinfection, the abdominal cavity was entered through a wide $U$-shaped incision encompassing the entire previous midline incision and the mesh, if present. This flap of the abdominal wall was excised after examination of the abdomen and the abdominal wall for adhesions using the macroscopic Zühlke score by 2 blinded researchers. ${ }^{[2]}$ The scoring system for the macroscopic classification of adhesions was as follows: No adhesions scored 0 , filmy adhesions that were easy to separate by blunt dissection scored I, stronger adhesions with the beginning of vascularization that partly required sharp dissection scored 2 , strong adhesions only separable by sharp dissection with clear vascularization scored 3 , and very strong adhesions, including abdominal organs with high risk of organ damage by dissection scored 4 . Swab cultures were taken following the examination of the abdominal cavity for the presence of abdominal abscesses. The resected abdominal wall was examined for the presence of abscess formation, mesh infection, and intestinal fistula. Then, under sterile conditions, every resected tissue was divided into 2 samples for tissue culture and histological examination. The samples taken for histological examination were first fixed in $10 \%$ formalin and then stained with hematoxylin and eosin after sectioning. The sections were then examined by a blinded histologist using a light microscope at 4-40x magnification for fibrosis, inflammatory cells (lymphocyte infiltration) and angiogenesis. The scale for grading of these parameters was as follows: 0, none; I, little/few; 2, moderate; 3, abundant. Adhesions were evaluated and scored according to the Zühlke microscopic scoring system. ${ }^{[12]}$ Microscopic scoring of adhesions was as follows. Loose connective tissue, an abundance of cells, old and new fibrin, and fine reticular fibers scored I. Connective tissue with cells, capillaries, and rare collagen fibers scored 2. Thicker connective tissue, few cells, more vessels, and few elastic and smooth muscle fibers scored 3. Old and firm granulation tissue, few cells, and hardly distinguishable serosal layers scored 4.

\section{Statistical Analysis}

Ten rats were designated to each group for a sample size that would maintain $80 \%$ power and a confidence interval of 
95\%. Statistical analysis was performed using SPSS for Windows, Version II .5 (SPSS Inc., Chicago, IL, USA). Descriptive statistics were presented as mean values $\pm S D$ for continuous numerical variables, and ordinal and nominal variables were presented as numbers and percentages. The significance of the difference between the groups in terms of the intensity of adhesions was assessed using the Mann-Whitney $U$ test. Fisher's exact test was used to examine the difference between nominal variables. Since the number of proliferating microorganisms in the cultures was not normally distributed, a logarithmic conversion was performed. After the logarithmic conversion, the significance of the difference between the 2 groups in terms of the number of microorganisms was examined using Student's t-test. A p value $<0.05$ was accepted as statistically significant.

\section{RESULTS}

An abundant growth of Gram-positive (Enterococci and Staphylococci) and Gram-negative (E. coli and Proteus) bacteria in the swab cultures taken from the abdominal cavity at the end of the $24^{\text {th }}$ hour after the induction of peritonitis proved the presence of bacterial contamination in both groups. All of the rats had findings of sepsis, such as apathy, piloerection, diarrhea, and ocular bleeding.

\section{Mortality}

In the first 48 hours after the second operation, 3 of the 20 subjects (15\%) died. All of the rats that died were in the mesh group. However, there was no statistically significant difference between the 2 groups in terms of mortality $(p=0.210)$.

\section{Macroscopic Adhesion Score}

The abdominal adhesions in the mesh group were significantly more intense when compared with the control group $(p=0.018)$ (Table I, Fig. I).

\section{Macroscopic Infection and Microbiological Findings}

Wound infection was macroscopically observed in 2 rats from the control group and 4 rats from the mesh group.

Table I. Macroscopic Zühlke scores

\begin{tabular}{lccccc}
\hline Intensity of adhesions & \multicolumn{2}{c}{$\begin{array}{c}\text { Control group } \\
(\mathbf{n}=10)\end{array}$} & & \multicolumn{2}{c}{$\begin{array}{c}\text { Mesh group } \\
(\mathbf{n}=7)\end{array}$} \\
\cline { 2 - 3 } \cline { 5 - 6 } & $\mathbf{n}$ & $\%$ & & $\mathbf{n}$ & $\%$ \\
\hline Grade 0 & 4 & 40.0 & & - & - \\
Grade I & 4 & 40.0 & & - & - \\
Grade 2 & - & - & & I & 14.2 \\
Grade 3 & - & - & & 3 & 42.9 \\
Grade 4 & 2 & 20.0 & 3 & 42.9 \\
\hline
\end{tabular}

A diagnosis of macroscopic infection was made if $I$ of the following was visualized: purulent discharge, subcutaneous abscess, enterocutaneous fistula, or mesh protrusion from the surgical wound. Although there were more macroscopic wound infections in the mesh group when compared with the control group (57.1\% and $20 \%$, respectively), this difference was not statistically significant $(p=0.162)$. None of

Table 2. Infection in the groups

\begin{tabular}{|c|c|c|c|c|c|}
\hline & \multicolumn{2}{|c|}{$\begin{array}{l}\text { Control } \\
\text { group } \\
(n=10)\end{array}$} & \multicolumn{2}{|c|}{$\begin{array}{l}\text { Mesh } \\
\text { group } \\
(n=7)\end{array}$} & \multirow[t]{2}{*}{$\mathbf{p}$} \\
\hline & $\mathbf{n}$ & $\%$ & $\mathbf{n}$ & $\%$ & \\
\hline WI (SA or MA) & 2 & 20.0 & 4 & 57.1 & 0.162 \\
\hline Abdominal abscess & - & - & - & - & - \\
\hline \multicolumn{6}{|l|}{ Proliferation in swab } \\
\hline cultures after sacrifice & 2 & 20.0 & 3 & 42.9 & 0.593 \\
\hline
\end{tabular}

MA: Mesh abscess; SA: Subcutaneous abscess; WI: Wound infection.

Table 3. Bacterial growth in the control and mesh groups

\begin{tabular}{|c|c|c|}
\hline & $\mathbf{A}$ & $\mathbf{B}^{*}$ \\
\hline \multicolumn{3}{|c|}{ Control group } \\
\hline Rat I & None & $54 \mathrm{cfu} / \mathrm{mL}$ \\
\hline Rat 2 & None & $1.000 \mathrm{cfu} / \mathrm{mL}$ \\
\hline Rat 3 & None & $1.433 \mathrm{cfu} / \mathrm{mL}$ \\
\hline Rat 4 & None & $8.0581 \mathrm{cfu} / \mathrm{mL}$ \\
\hline Rat 5 & 8 colonies of E. coli & $3.827 \mathrm{cfu} / \mathrm{mL}$ \\
\hline Rat 6 & None & $78 \mathrm{cfu} / \mathrm{mL}$ \\
\hline Rat 7 & None & $69.629 \mathrm{cfu} / \mathrm{mL}$ \\
\hline Rat 8 & 2 colonies of E. coli & $652 \mathrm{cfu} / \mathrm{mL}$ \\
\hline Rat 9 & None & $18.615 \mathrm{cfu} / \mathrm{mL}$ \\
\hline Rat 10 & None & $31.333 \mathrm{cfu} / \mathrm{mL}$ \\
\hline \multicolumn{3}{|c|}{ Mesh group } \\
\hline Rat I & None & $1.612 .500 \mathrm{cfu} / \mathrm{mL}$ \\
\hline Rat 2 & None & I.208.727 cfu/mL \\
\hline Rat 3 & $\begin{array}{c}>100 \text { colonies of } \mathrm{E} . \text { coli }+ \\
\text { Bacillus species }\end{array}$ & I I.835.333 cfu/mL \\
\hline Rat 4 & None & $1.619 .470 \mathrm{cfu} / \mathrm{mL}$ \\
\hline Rat 5 & None & $201.000 .000 \mathrm{cfu} / \mathrm{mL}$ \\
\hline Rat 6 & $\begin{array}{c}>100 \text { colonies of } E \text {. coli }+ \\
\text { Bacillus species }\end{array}$ & $3.210 .454 \mathrm{cfu} / \mathrm{mL}$ \\
\hline Rat 7 & $\begin{array}{c}>100 \text { colonies of E.coli }+ \\
\text { Bacillus species }\end{array}$ & $25.782 .857 \mathrm{cfu} / \mathrm{mL}$ \\
\hline
\end{tabular}

A: Bacterial growth in abdominal swab cultures taken on the day of sacrifice; B: Bacterial growth in mesh/tissue cultures. *The growth in the mesh/tissue cultures consisted of $E$. coli in the control group and E. coli, Enterococci, and Bacteriodes species in the mesh group. cfu: Colony forming unit. 


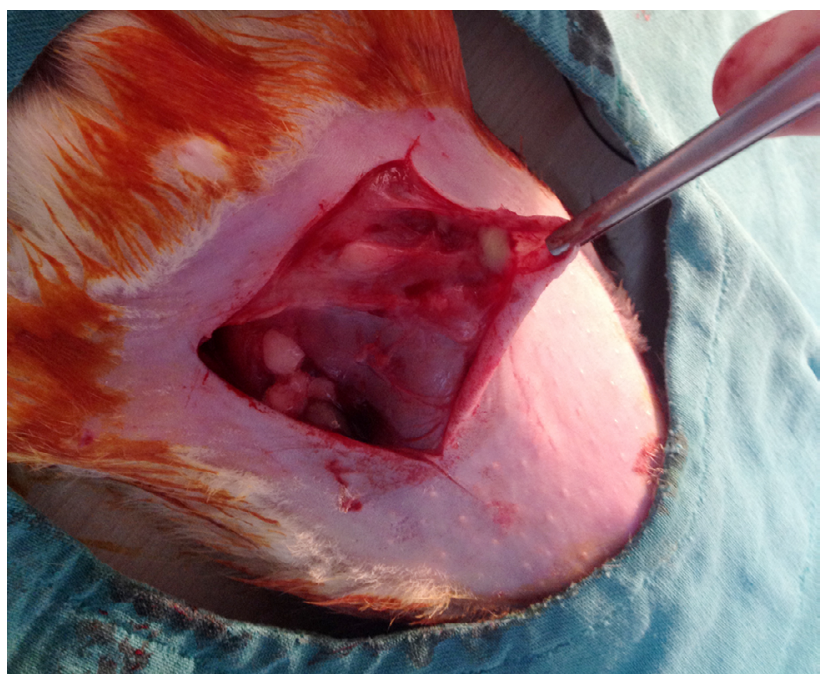

Figure 1. Macroscopic view of Grade 4 adhesions in the mesh group with a focus of mesh abscess near the tip of the surgical instrument

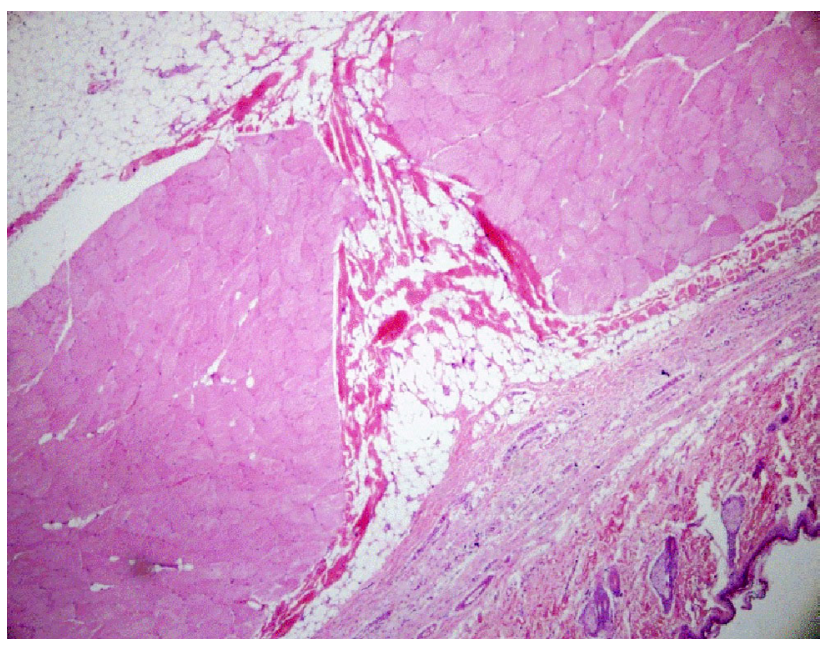

Figure 2. Grade 0 adhesion in the control group (Adipocytes can be seen in the subcutaneous tissue. There are no inflammatory cells or fibrosis) Hematoxylin and eosin x4 magnification.

the rats in either of the groups demonstrated evidence of abdominal abscesses. There was also no significant difference between the groups with regard to bacterial growth in the swab cultures that were taken on the day of sacrifice $(p=0.593)($ Table 2$)$.

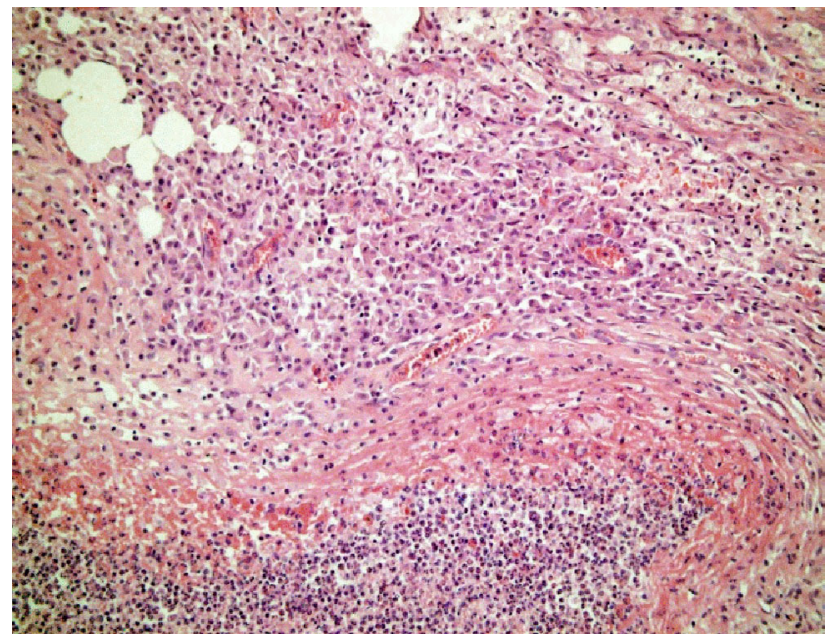

Figure 3. A section from the mesh group. Neutrophils and lymphoplasmocyte infiltration accompanied by histiocytes beneath them can be seen on the abscess wall. Hematoxylin and eosin x20 magnification.

There was bacterial growth in all of the tissue and mesh/tissue samples taken from both groups. The mean number of proliferating bacteria in the mesh/tissue cultures was $7.99 \pm 5.49$ in the control group and $15.72 \pm 1.88$ in the mesh group (after logarithmic conversion) $(\mathrm{p}=0.003)$ (Table 3 ).

\section{Histopathological Findings}

The scores for inflammatory cell infiltration, fibrosis, and neovascularization, as well as the microscopic Zühlke scores were significantly higher in the mesh group when compared with the control group $(p=0.003, p=0.005, p=0.002$, and $\mathrm{p}<0.00 \mathrm{I}$, respectively) (Figs. 2 and 3; Table 4).

\section{DISCUSSION}

Mesh infection after ventral hernia surgery is a substantial problem, causing a high risk of hernia recurrence and increasing the incidence of reoperation, the length of hospital stay, and the financial burden on the healthcare system. ${ }^{[13,14]}$ Especially in cases with contamination (i.e., fascia defects caused by gunshot wounds, necrotizing fasciitis, cases of hernia with strangulation or intestinal perforation, parastomal hernia, etc.), there is an increased incidence of mesh infections. ${ }^{[8]}$ It is asserted that among synthetic meshes, lightweight, mi-

Table 4. Histopathology scores

\begin{tabular}{lccr}
\hline Variables & Control $(\mathbf{n}=\mathbf{1 0})$ & Mesh $(\mathbf{n}=\mathbf{7})$ & $\mathbf{p}$ \\
\hline Zühlke microscopic adhesion score & $\mathrm{I}(0-2)$ & $2(2-3)$ & $<0.001$ \\
Inflammatory cell infiltration score & $\mathrm{I}(0-2)$ & $2(2-3)$ & 0.003 \\
Neovascularisation score & $\mathrm{I}(0-2)$ & $2(2-3)$ & 0.002 \\
Fibrosis score & $\mathrm{I}(0-2)$ & $2(1-3)$ & 0.005 \\
Total score & $4.5(0-7)$ & $9(8-11)$ & $<0.001$ \\
\hline
\end{tabular}


croporous, polypropylene materials have a greater tendency to be resistant to infection. Recent technological advances have enabled these lightweight polypropylene meshes to be produced without the disadvantage of decreased mechanical resistance, thereby minimizing the foreign body reaction polypropylene triggers in the body and decreasing the likelihood of infection and increasing patient comfort due to less fibrosis and rigidity. ${ }^{[15,16]}$

Ventralight ST, which was used in this study, is a composite mesh with a lightweight polypropylene component and an absorbable adhesion barrier that is composed of chemically modified sodium hyaluronate, carboxymethylcellulose, and polyethylene glycol-coated polyglycolic acid fibers. ${ }^{[1]]}$

In this study, the feasibility of intraperitoneal synthetic mesh application in the presence of abdominal infection was investigated. The cecal ligation and perforation model was used to create bacterial peritonitis in rats and the outcomes of a control group with no mesh and a mesh group were compared. Although there was no significant difference between the 2 groups in the macroscopic findings of infection, there was an apparent tendency for macroscopic infection in the mesh group. In studies that argue for the safety of synthetic mesh application in contaminated fields, which inspired this experimental study, the rate of mesh infection was reported to be around $20 \%{ }^{[8-10]}$ Although the reasons for this marked difference between these reported results and those of the present study $(57.1 \%$ macroscopic infection in the mesh group in the present study versus $20 \%$ in previous studies) may be more complicated, the authors believe that I possible reason may be the severity of the experimental septic peritonitis in this study.

One of the parameters that were evaluated in this experimental trial was the severity of adhesions, as adhesions are a feared complication of surgical operations performed in the presence of abdominal infections, causing significant rates of morbidity and mortality. In the present study, there were significantly more adhesions in the mesh group. This finding demonstrates that the use of synthetic materials distinctly increases adhesions in the presence of infection, and the intraperitoneal application of these materials in infected surgical fields cannot be considered sufficiently safe even with an adhesion barrier. What is more, the scores for inflammatory cell infiltration, neovascularization, and fibrosis were significantly higher in the mesh group, indicating an increased inflammatory response in the hosts with prosthetic meshes applied in the presence of infection. Although a Cochrane meta-analysis has reported the benefit of hyaluronate/carboxymethylcellulose membrane in decreasing abdominal adhesions, ${ }^{[18]}$ in the present trial, it may be speculated that inflammatory reaction eliminated this anti-adhesive effect, causing increased adhesions in the mesh group.

The most interesting finding of the current study was the death of 3 rats in the mesh group ( $30 \%$ mortality), whereas no mortality was encountered in the control group. The authors comment that this may indicate a heavier septic burden in the mesh group and that the rats in this group may have had a weaker immune defense against bacterial infection. Also, the significantly higher bacterial count in the tissue-mesh cultures in the mesh group demonstrated that the synthetic material in this group may be a suitable environment for easier bacterial growth. This was speculated to be the explanation for the higher mortality rate in the mesh group.

This study has several limitations that deserve mentioning. First of all, there is significant difference between rats and humans with regard to the proportion of the size of the mesh and the mesh pores to the size of the abdominal wall. Also, the mesh used in this experiment was fixated with 6 sutures. In humans, the number of fixation points in proportion to the mesh size would be much higher. These limitations mean that the findings of the present study are difficult to adapt to humans. Secondly, the completion of this study on the $28^{\text {th }}$ day, and the absence of biomechanical parameters like mesh tension strength, prevent offering any opinions regarding late complications. Finally, the body concentration of the antiadhesives in the adhesion barrier and their systemic effects during breakdown in this model might be different in humans. In conclusion, the findings of this study demonstrate that the use of this synthetic composite mesh, composed of lightweight polypropylene, hyaluronate, carboxymethylcellulose, polyethylene glycol, and polyglycolic acid, in the infected abdomen is not favorable and it is still imperative to be very selective and cautious regarding the use of synthetic materials in the presence of severe abdominal contamination. There is still a need for more experimental research with stronger statistical power that will further contribute to this subject.

\section{Conflict of interest: None declared.}

\section{REFERENCES}

1. Den Hartoq D, Dur AH, Tuinebreijer WE, Kreis RW. Open surgical procedures for incisional hernias. Cochrane Database Syst Rev 2008;16:CD006438. [CrossRef]

2. Choi JJ, Palaniappa NC, Dallas KB, Rudich TB, Colon MJ, Divino C. Use of mesh during ventral hernia repair in clean-contaminated and contaminated cases: outcomes of 33,832 cases. Ann Surg 2012;255:176-80.

3. Shankaran V, Weber DJ, Reed L, Luchette FA. A review of available prosthetics for ventral hernia repair. Ann Surg 2011;253:16-26. [CrossRef]

4. Hiles M, Record Ritchie RD, Altizer AM. Are biologic grafts effective for hernia repair?: a systematic review of the literature. Surg Innov 2009;16:26-37. [CrossRef]

5. Catena F, Ansaloni L, Gazzotti F, Gagliardi S, Di Saverio S, D’Alessandro $\mathrm{L}$, et al. Use of porcine dermal collagen graft (Permacol) for hernia repair in contaminated fields. Hernia 2007;11:57-60. [CrossRef]

6. Bellows CF, Shadduck PP, Helton WS, Fitzgibbons RJ. The design of an industry-sponsored randomized controlled trial to compare synthetic mesh versus biologic mesh for inguinal hernia repair. Hernia 2011;15:325-32. [CrossRef]

7. Smart NJ, Marshall M, Daniels IR. Biological meshes: a review of their use in abdominal wall hernia repairs. Surgeon 2012;10:159-71. [CrossRef] 
8. Carbonell AM, Cobb WS. Safety of prosthetic mesh hernia repair in contaminated fields. Surg Clin North Am 2013;93:1227-39. [CrossRef]

9. Carbonell AM, Criss CN, Cobb WS, Novitsky YW, Rosen MJ. Outcomes of synthetic mesh in contaminated ventral hernia repairs. J Am Coll Surg 2013;217:991-8. [CrossRef]

10. Deerenberg EB, Mulder IM, Grotenhuis N, Ditzel M, Jeekel J, Lange JF. Experimental study on synthetic and biological mesh implantation in a contaminated environment. Br J Surg 2012; 99:1734-41. [CrossRef]

11. Hubbard J, Choudry M, Schwacha MG, Kerby JD, Rue LW 3rd, Bland KI, et al. Cecal ligation and puncture. Shock 2005;24:52-7. [CrossRef]

12. Sortini D, Feo CV, Maravegias K, Carcoforo P, Pozza E, Liboni A, et al. Role of Peritoneal Lavage in Adhesion Formation and Survival Rate in Rats: An Experimental Study. J Invest Surg 2006;19:291-7. [CrossRef]

13. Leber GE, Garb JL, Alexander AI, Reed WP. Long-term complications associated with prosthetic repair of incisional hernias. Arch Surg 1998;133:378-82. [CrossRef]
14. Sadava EE, Krpata DM, Gao Y, Novitsky YW, Rosen MJ. Does presoaking synthetic mesh in antibiotic solution reduce mesh infections? An experimental study. J Gastrointest Surg 2013;17:562-8. [CrossRef]

15. Li J, Ji Z, Zhang W, Li L. The comparison of lightweight mesh and standard mesh in incisional hernia repair with the open sublay technique: the results of a meta-analysis. Surg Laparosc Endosc Percutan Tech 2015;25:238-44. [CrossRef]

16. Díaz-Godoy A, García-Ureña MA, López-Monclús J, Vega Ruíz V, Melero Montes D, Erquinigo Agurto N. Searching for the best polypropylene mesh to be used in bowel contamination. Hernia 2011;15:173-9.

17. Deeken CR, Matthews BD. Ventralight ST and Sorbafix versus Physiomesh and securestrap in a porcine model. JSLS 2013;17:549-59.

18. Kumar S, Woung PF, Leaper DJ. Intra-peritoneal prophylactic agents for preventing adhesions and adhesive intestinal obstruction after nongynaecological abdominal surgery. The Cochrane Database Syst Rev 2009;21:CD005080. [CrossRef]

\section{DENEYSEL ÇALIŞMA - ÖZET}

\section{Karın içi enfeksiyon varlığında sentetik yama kullanımı: Deneysel bir uygulanabilirlik çalışması}

\section{Dr. Ahmet Burak Çiftci, ${ }^{1}$ Dr. Rıza Haldun Gündoğdu, ${ }^{2}$ Dr. Bahadır Osman Bozkırlı, ${ }^{3}$ Dr. Mustafa Ömer Yazıcıoğlu, ${ }^{2}$ Dr. Berrak Gümüşkaya Öcal, ${ }^{4}$ Dr. Birsen Özdem ${ }^{5}$}

${ }^{1}$ Bingöl Devlet Hastanesi, Genel Cerrahi Kliniği, Bingöl

${ }^{2}$ Ankara Atatürk Eğitim ve Araştırma Hastanesi, Genel Cerrahi Kliniği, Ankara

${ }^{3}$ Ankara Eğitim ve Araştırma Hastanesi, Genel Cerrahi Kliniği, Ankara

${ }^{4}$ Ankara Atatürk Eğitim ve Araştırma Hastanesi, Patoloji Kliniği, Ankara

${ }^{5}$ Ankara Atatürk Eğitim ve Araştırma Hastanesi, Mikrobiyoloji Kliniği, Ankara

AMAÇ: Sentetik malzemelerin kontamine alanlarda kullanımı ile ilgili farklı görüşler mevcuttur. Bu çalışma, ticari olarak erişilebilen kompozit yamalardan birinin karın içi enfeksiyon varlığında kullanılabilirliğini araştırmayı amaçlamaktadır.

GEREÇ VE YÖNTEM: Yirmi adet sıçanda deneysel peritonit oluşturulmasından 24 saat sonra, denekler iki adet onarlı gruba randomize edildi. İkinci bir laparotomi ile karın içinin temizlenmesini takiben karın kontrol grubunda sürekli sütürlerle, deney grubundaysa kompozit yama kullanılarak kapatıldı. Bundan sonra sıçanlar sepsis bulguları, ölüm ve yara yeri enfeksiyonu açısından takip edildi. Yirmi sekizinci günde sıçanlar sakrifiye edilerek karın içi enfeksiyon, karın içi yapışıkııklar açısından ve alınan yama ve doku örnekleri de kültür üremeleri açısından değerlendirildi.

BULGULAR: Mortalite oranları kontrol ve yama gruplarında sırasıyla \%0 ve \%30 $(p=0.21)$ ve yara yeri enfeksiyonu oranları ise sırasıyla \%20 ve \%57.l'di $(p=0.162)$. Yama grubunda yapışılıklar istatistiksel olarak önemli biçimde daha yoğundu $(p=0.018)$ ve doku kültürlerinde önemli ölçüde daha fazla mikroorganizma üremişti $(p=0.003)$.

TARTIŞMA: Yama grubunda karın içi yapışı|klıkların yoğunluğunun ve bakteri üremesinin önemli ölçüde daha fazla olması ve aynı zamanda mortalite ve yara yeri enfeksiyonu oranlarındaki artış eğilimi, bu kompozit yamanın, karın içi enfeksiyon varlığında karın defektlerinin onarımı için güvenle kullanılamayacağını göstermektedir.

Anahtar sözcükler: Enfekte alan; karın içi yapışıklık; peritonit; yama enfeksiyonu.

Ulus Travma Acil Cerrahi Derg 20 I8;24(6):50I-506 doi: 10.5505/tjtes.2018.59263 